\title{
Taking the Fight to Them: Neighborhood Human Rights Organizations and Domestic Protest
}

\author{
SAM R. BELL, TAVISHI BHASIN, K. CHAD CLAY AND \\ AMANDA MURDIE*
}

This article examines how human rights international non-governmental organizations (hereafter HROs) can increase the level of political protest in neighboring states. Previous research suggests local activities of HROs help to generate mobilization for protests against governments. This article shows that the presence of HROs in neighboring states can be a substitute for domestic HROs; if domestic HROs are already flourishing, there will be less of a 'neighbor' effect. At sufficiently high levels of domestic HRO prevalence within a state, neighboring HROs help domestic HROs use institutionalized substitutes for protest mobilization strategies. Spatial econometric methods are used to test the implications of this theory. These results illuminate the role that non-governmental organizations play in these domestic political processes, and demonstrate the transnational nature of their activities.

Non-violent political protest is a direct vehicle for citizens to express their views to their governments in order to demand and engender political change. The achievements of protest movements are numerous and include historical landmarks like the granting of greater civil rights to the African American community in the United States, the end of apartheid in South Africa, the end of British colonialization in India, and the sparking of democratization processes across post-Soviet countries. Civil society organizations, especially organizations that promote democracy or have a human rights focus, are often important catalysts for these protests. They help organize people on the ground, provide them resources for successful protest activities, including training on non-violent protest techniques, material resources for these activities, and information on the location of targets. Thus, countries with a rich array of civil society organizations, like South Africa or the United States, are able to mobilize civilians to bring about seminal political changes successfully. If civil society organizations are a key catalyst to non-violent protest, how do protest movements achieve their goals when their countries lack a vibrant civil society sector? Are citizens in these states simply less able to organize and participate in non-violent protest, limiting their recourse to political change? Or, could civil society organizations in neighboring states help serve this catalyzing role in the absence of a developed domestic sector?

In this article, we argue that civil society organizations both within a state and in the geographic neighborhood of a state can serve to increase the occurrence of domestic non-violent anti-government protests. This implies that states with weak civil

* Kansas State University (email: sbell3@k-state.edu); Kennesaw State University (email: tbhasin@kennesaw.edu); University of Georgia (email: kcclay@uga.edu); University of Missouri (email: murdiea@missouri.edu). An earlier version of this article was presented at the 2011 Annual Peace Science Society Meeting hosted at the University of Southern California. We thank the participants of that meeting for their helpful comments. We also thank two anonymous reviewers and the Editor for their constructive and helpful comments. An online appendix with supplementary tables and replication data is available at http://dx.doi.org/doi:10.1017/S0007123413000100. All authors contributed equally and are thus listed in alphabetical order. 
society sectors can still experience popular protests that help spark political change, particularly when the advocacy gap left by a lack of domestic civil society organizations is filled by organizations in neighboring states helping to mobilize citizens from across the border.

Indeed, examples of such cross-border activity abound. In Eastern Europe after the fall of the Soviet Union, for instance, civil society organizations often worked across borders to encourage non-violent protests in countries without a strong domestic civil society sector, which often led to political transformation. Organizations within Romania, Czechoslovakia, Serbia, Georgia, and Ukraine had a strong influence on democratization processes in neighboring countries. ${ }^{1}$ Based on their previous domestic experiences with democratization, members of organizations from these countries that promote rights crossed borders and shared successful techniques and experiences with citizens in neighboring states, helping to bring about the 'electoral revolutions' key to the third wave of democracy. Romanians and Bulgarians helped the Slovaks, the Slovaks in turn helped Croatians and Serbians, and Serbians and Georgians helped Ukrainians to bring about the 'Orange Revolution' that captured world attention in 2004 and $2005 .^{2}$

More recently, in 2011, as protests swept the Middle East and North Africa, members of organizations set up to promote rights served as important conduits for domestic mobilization and coordination resources. Not all organizations playing an active role in mobilizing non-violent protest in the region had members based in the state where the protests were occurring. Instead, these organizations were able to contribute by sending their members across borders from neighboring countries. Syria is a potent case. Even before the first non-violent protests started within the country, rights-promoting organizations from neighboring countries had a firm presence within the state. In fact, starting in 2007, European Union programs for promoting democracy in Syria had made use of organizations from Lebanon; other organizations, like Human Rights Watch, had made use of members from Jordan and Turkey. ${ }^{3}$ In a way, the work of organizations from neighboring states in Syria was filling in or substituting for domestic civil society activities, which even the First Lady of Syria, Asma Al-Assad, has noted were historically absent. ${ }^{4}$

While the above illustrations highlight that cross-border activism can play a key role in non-violent protest, there has been little work in political science aimed at determining the degree to which this dynamic plays out generally. Thus, in order to begin addressing this important topic, we focus on the degree to which international civil society organizations work across borders, concentrating on one particular type of organization: international human rights-promoting non-governmental organizations (human rights INGOs or, as used hereafter, HROs). The activities of HROs provide the best example of civil society organizations participating in this cross-border activism. HROs campaign globally for a broad variety of rights, including civil rights, women's and children's rights, and personal security from imprisonment and torture. HROs also promote human security broadly defined, including rights to housing, a safe and clean environment, and a basic standard of living. The extant literature is also clear that HROs use several different mechanisms to achieve their rights-promotion goals, including education, international advocacy, and

1 Bunce and Wolchik 1996.

2 Bunce and Wolchik 1996, 12.

3 EEAS 2011; Human Rights Watch 2011.

4 Al-Assad 2010. 
the promotion of non-violent protest techniques. ${ }^{5}$ Thus, HROs' broad focus and range of strategies provides us with a particularly rich sub-sample for studying the work of international civil society organizations and their effects on domestic non-violent protest across borders.

The theory predicts that the intensified domestic mobilization that accompanies nonviolent protest is a necessary step in the processes through which political change, human rights improvements, and democratization occur. ${ }^{6}$ The argument developed here suggests that, given the finite resources of organizations composed of rational actors, we should observe substitution of advocacy: when local organizations are underdeveloped, members of organizations from neighboring countries ('neighborhood HROs') lend a helping hand to aid domestic non-violent protest. In addition to our advocacy substitution argument, and similar to Pippa Norris's idea of 'repertoires' of political action, we posit that the interactions of domestic and neighboring HROs also display a ceiling effect, where neighborhood HROs, if aiding domestic political action at all, work through a substitution of strategies dynamic. ${ }^{7}$ When domestic HROs are strongly established and effectively able to influence mobilization themselves, we do not expect larger numbers of neighborhood HROs to lead to more non-violent protest. If anything, in this situation, we expect high numbers of neighborhood HROs to be associated only with less visible advocacy behaviors, which typically serve as more viable substitutes for non-violent protest in those countries allowing for a vibrant civil society sector.

We examine the testable implications of our theoretical argument using a dataset of domestic and neighborhood HROs worldwide from 1990 to 2003. We find support for our overall arguments: advocacy from organizations geographically connected to the state can substitute for the increased occurrence of non-violent protest from domestic HROs. At high levels of domestic and neighborhood involvement, however, we find diminishing returns. This is consistent with our arguments of both advocacy substitution and strategy substitution.

What are the broader implications of these theoretical arguments? First, this study advances our understanding of the processes through which HROs work to promote rights. It highlights a fundamental causal logic of HRO behavior, demonstrating how organizational constraints and opportunity structures influence strategies and, consequently, when and where we will see organizations influence domestic non-violent protest 'beyond borders'. This logic contradicts the predominant view that a greater number of organizations have a proportional linear and positive effect on mobilization and advocacy outcomes. This 'more is better' understanding of advocacy has dominated the literature. ${ }^{8}$ Instead of more HROs automatically leading to more non-violent protest, more HROs can influence a change in strategies from non-violent protest to more direct participation in institutional methods such as voting and lobbying. This study of the effects of neighborhood HROs on domestic non-violent protest also furthers our understanding of the necessity for domestic civil society to have developed to a certain

5 Franklin 2008; Keck and Sikkink 1998; Risse, Ropp, and Sikkink 1999; Ron, Ramos, and Rodgers 2005; Murdie and Bhasin 2011; Schmitz 2002.

6 Risse, Ropp, and Sikkink 1999.

7 Norris 2002.

${ }^{8}$ Notable exceptions to this idea include Cooley and Ron (2002), with reference to proliferation of service as opposed to advocacy organizations, and a formal model by Aldashev and Verdier (2010), that outlines a tipping point hypothesis about development NGOs. 
degree as a precondition for such a protest. HROs that are not active within the target country can still influence non-violent protest mobilization through their members in neighboring states. This understanding of domestic-international interplay is important not just for those interested in 'second-image reversed' scholarship but also for international policy makers who want to influence mobilization in states with a nascent civil society.

Below, after outlining the extant literature on HRO involvement in domestic mobilization, we develop our theoretical argument on the substitution of advocacy and substitution of strategies. We then present our research design and main empirical findings. Further discussions highlight the ways in which strategies can be substituted at high levels of domestic HRO involvement. We conclude by further delineating the theoretical contribution of this research and its broader implications for the larger community promoting human rights and democracy.

\section{EXISTING PERSPECTIVES ON HROS AND NON-VIOLENT PROTEST MOBILIZATION}

How do HROs affect the occurrence of non-violent protest? Initially, non-violent protests require coordination resources, like communication devices, organizers, and meeting spaces, for domestic actors. ${ }^{9}$ Often, these resources are provided by organizations. Kriesi distinguishes between four types of formal organizations who may all be working for similar goals and influence non-violent protest within a state: (1) parties and interest groups who may help represent the common goals in the institutional arena, (2) support organizations such as friendly media and churches, (3) movement associations created to cater to the daily needs of movement members and to help maintain commitment, and, finally, (4) social movement organizations themselves. ${ }^{10}$ Social movement organizations are distinguished from all other formal organizations by one singular feature - they work directly to mobilize citizens for their cause and are in turn dependent on successful mobilization to achieve their organizational goals. Kriesi uses Amnesty International, a prominent $\mathrm{HRO}$, as a prime example of a social movement organization that has increased non-violent protest mobilization in Europe. ${ }^{11}$

Indeed, it seems that there is good reason to suspect that HROs seek out domestic protest movements to support. A significant strain of the larger literature on civil society organizations and funding agencies highlights how domestic actors using non-violent actions often receive more resources than those using violent actions through the radical flank effect. ${ }^{12}$ Here, domestic actors that use non-violent actions are seen as more legitimate and, thus, receive greater resources and assistance from foundations and organizations. An additional reason for prioritizing support to these non-violent actors includes the political success associated with these non-violent strategies. ${ }^{13}$

The role of international and domestic civil society organizations, both with and without a human rights focus, in mobilizing domestic non-violent protest is also well established in the protest literature on the United States. For example, Heaney and Rojas surveyed 5,410 demonstrators in anti-war protests in the United States and found that the majority of protesters were connected to at least one international or

\footnotetext{
9 Andrews and Biggs 2006; Haines 1984.

10 Kriesi 1996.

11 Kriesi 1996.

12 Haines 1984.

13 Stephan and Chenoweth, 2008.
} 
domestic organization. ${ }^{14}$ In line with the classic social mobilization literature, these organizations serve to connect individuals to the overall movement, increasing their participation. $^{15}$

Within the literature on HROs themselves, there is also a focus on how organizations must mobilize domestic non-violent protest in order to achieve their larger rightspromotion goals. Although this literature also highlights the role HROs have in international advocacy (i.e. 'shaming and blaming'), Keck and Sikkink's transnational advocacy network or 'boomerang' framework rests on the idea that HROs, when called by a domestic population, help mobilize domestic opposition to repressive government practices. ${ }^{16}$ The subsequent spiral model of Risse, Ropp, and Sikkink also stresses that domestic mobilization is necessary to ensure that international advocacy results in sustained democratization or political change. ${ }^{17}$

Likewise, there is an extensive case study literature documenting the effects of HROs on non-violent protest. For example, Schock highlights the role of HROs in aiding domestic non-violent protest in the Philippines in the early 1980s through their advocacy efforts and provision of material resources, such as providing space for protesters to gather. ${ }^{18}$ A second example is that of HROs providing essential training on non-violent protest strategies, resources, and advocacy support in South Africa. ${ }^{19}$ As mentioned, the Orange Revolution in Ukraine was strongly dependent on HROs and other organizations providing training and material resources to non-violent protesters, including cell phones, which helped activists stay in better communication. ${ }^{20}$ Boulding finds similar dynamics in Bolivia in 1999 and 2004 where organizations provided 'financial, educational, [and] infrastructural' resources to aid in political participation. ${ }^{21}$

Cross-nationally, Murdie and Bhasin find support for HRO presence yielding greater levels of domestic non-violent protest through 'field-building'. HROs serve to expand the 'field' of domestic actors by connecting them to a larger network of goods and people who can aid their mobilization efforts. This direct intended effect on non-violent protest events is differentiated by Murdie and Bhasin from the unintended diffusion effect of HROs on violent protest, where there is inadvertent use of HRO resources by domestic actors utilizing violent strategies. ${ }^{22}$

Although the above literature has greatly expanded our understanding of the effects of civil society organizations, including HROs, on non-violent protest, the majority of this literature focuses on what happens within a domestic context - how international organizational presence within the borders of a country influences domestic groups to increase mobilization. To reiterate, this extant literature does focus on how international organizations can be involved domestically; what is largely missing, however, is how externally-based resources and members of international organizations cross borders and become involved in domestic mobilization. This is problematic: if, as Keck and Sikkink make clear, rights-promoting organizations are supposed to work to answer domestic

14 Heaney and Rojas 2011.

15 McAdam, Tarrow, and Tilly 2001.

16 Keck and Sikkink 1998.

17 Risse, Ropp, and Sikkink 1999.

18 Schock 2005.

19 Taylor 2002.

20 Wallander 2005.

21 Boulding 2010, 458.

22 Murdie and Bhasin 2011. 
demands for assistance, we need a more concrete understanding of which organizations are going to respond to these calls. ${ }^{23}$ This is also important for rights-promotion. As many repressive regimes restrict the work of organizations critical of the regime inside their borders, organizations have to be more creative in how they can deliver coordination goods to aid non-violent protest movements, particularly in those states with a limited or nascent civil society. ${ }^{24}$

The literature on coordination resources and non-violent protest clearly lays out that protest resources diffuse across geographic locations and across groups. ${ }^{25}$ Specifically on organizational resources, Bell, Clay, and Murdie argue, in line with the boomerang or transnational advocacy network model, that organizations in neighboring states can serve as 'first responders' providing assistance and fostering mobilization that ultimately leads to improvements in human rights. Bell, Clay, and Murdie find support for this argument in a global sample of countries in the post-Cold War era. Although Bell, Clay, and Murdie take us one step closer to understanding the role of HROs across borders, the authors focus on the more distant outcome of ultimate improvement in human rights records and not on the more crucial intermediate step of domestic non-violent protest. ${ }^{26}$

Another missing component in the broader literature is a theoretical discussion of how organizations within a country and within the geographic neighborhood interact in mobilization efforts. If there is a real coordinated or network factor at work in rightspromotion organizational advocacy behavior, we should expect the work of organizations domestically and organizations within the neighborhood to condition each other. ${ }^{27}$ Thus, if Bell, Clay, and Murdie's causal story is correct, we should expect neighborhood organizations to work to promote democracy and improve human rights by mobilizing domestic actors to protest non-violently against their state. ${ }^{28}$ Because of this, countries without a strong HRO presence may still have active protest mobilization through the utilization of resources from organizations in neighboring states. We present a descriptive case example of this process below.

\section{NEIGHBORHOOD HROS AND NON-VIOLENT PROTEST IN BURMA}

Cases of non-violent protest in Burma (Myanmar) illustrate the role played by neighborhood HROs when domestic organizations were not allowed a strong presence, if one at all. For the years that we have data, Burma had an average of 9.8 HROs with members in the state, while its neighbors had an average of 37.7 such organizations with a member presence across the same time period. Since military junta rule in 1962, gross human rights abuses and a closed political system have suppressed all domesticallyorganized dissent, and led the country, once rich in natural resources, to become one of the least developed in the world. ${ }^{29}$

Burma has seen a strong opposition movement led by the National League of Democracy and its members, but this opposition movement has largely not involved

${ }^{23}$ Keck and Sikkink 1998.

${ }^{24}$ ICNL 2009.

${ }^{25}$ Andrews and Biggs 2006; Haines 1984.

${ }^{26}$ Bell, Clay, and Murdie 2012.

${ }^{27}$ DeMars, 2005; Keck and Sikkink, 1998.

${ }^{28}$ Bell, Clay, and Murdie 2012.

29 Burma Profile. BBC News. Last accessed on 8 August 2012 from http://www.bbc.co.uk/news/worldasia-pacific-12990563. 
ordinary citizens. ${ }^{30}$ Two exceptions to this are the largely non-violent protests of 1988 and the protests of 2007. Both protest periods saw hundreds of thousands of Burmese come out in the streets to demand full democracy. Both periods also had the same two sets of protagonists, students and Buddhist monks. These protests, the latter set in particular, were essential in bringing about the slow democratic reforms the military junta has undertaken, including the opening of the April 2012 parliamentary elections to opposition members of the National League for Democracy.

HRO volunteers in neighboring countries, particularly from organizations based in Thailand, provided critical support and resources to these protest movements. After a government crackdown in 1988, many protestors fled to the border region of Thailand to escape torture and imprisonment at the hands of the junta. Some went on to form the Forum for Democracy in Burma (FDB). The FDB is a coalition of student organizations, women's groups and workers' unions based in Thailand. The FDB groups also have links with students and party workers inside Burma. ${ }^{31}$ In 2007, it was student groups associated with the FDB that led the protests which later turned into the 'saffron revolution' supported by the monks.

Groups like the FDB work from their bases in Thailand to empower Burmese actors and document atrocities committed by the military junta, sharing this information with world media and members of other HROs, such as Amnesty International and Human Rights Watch, which then help bring greater world attention to events within Burma. ${ }^{32}$ Amnesty International, for example, also works from their base in Thailand on human rights education with the larger goal of conflict alleviation and reduction of human rights abuses against the Burmese people, especially the Karen ethnic group. Officials from Amnesty International have written on the rich network of organizations in the Thai border area working on the same goals. ${ }^{33}$

Founded in Thailand in 2006, Burma Partnership is another large regional forum consisting of groups scattered across Indonesia, Japan, Hong Kong, Korea, and the Philippines. ${ }^{34}$ Its mission is to improve collaboration between Burmese pro-democracy groups and solidarity groups around Asia. Burma Partnership provides Amnesty International's campaigning manual to all its activists on their website and links directly to reports by Amnesty International and Human Rights Watch on Burma. At a rally held in the Philippines in 2010, Amnesty International members and others called for nonviolent dialogue to be held between the military junta and the opposition. ${ }^{35}$ Recently, Burma's main opposition leader publicly acknowledged the support of Amnesty International members for her campaign for democratic reforms in Burma. ${ }^{36}$ The organization worked to send resources to the country, such as thousands of radios and

30 Beer 1999.

31 Forum for Democracy in Burma's website in English - http://en.fdburma.org. The About Us and Members section lists these groups and their location along the Burma-Thailand border.

${ }^{32}$ http://www.amnesty.org/en/library/asset/ASA16/007/2009/en/ale17ccc-9353-418c-a04f-faee4bdb9249/ asa160072009en.html.

33 A Personal Experience on the Thai-Burma Border. Wendy Hughes. Amnesty International. http:// bathamnesty.org.uk/2012/05/20/a-personal-experience-on-the-thai-burma-border.

34 Burma Partnership Website. Section called Tools for Activists. http://www.burmapartnership.org/ tools-for-activists.

${ }^{35}$ http://burmapartnership.org/2010elections/2010/11/activists-urge-burmese-junta-to-start-genuinedialogue-with-opposition.

36 http://www.amnesty.org.nz/news/timeline-aung-san-suu-kyi-and-amnesty-international. 
several sets of walkie-talkies and satellite kits, which have been delivered to citizens in remote areas of the country to keep them informed of their rights and the support they have internationally. ${ }^{37}$ In such ways, HROs from neighboring countries have direct local impact on Burmese opposition movements through these resource initiatives. Indeed, it appears that the vacuum of civil society organizations inside Burma, which has been created through fear of persecution by the Burmese military junta, is being actively filled by civil society organizations led by citizens in exile in partnership with members of HROs from within neighboring states.

\section{THEORY}

Given the existing literature, together with a multitude of anecdotal cases, we argue that neighborhood HROs can substitute for domestic HROs in mobilizing non-violent protest. We also argue, however, that, when there are high levels of domestic HROs within a country already, neighborhood HROs are less likely to aid domestic groups. In cases where they do aid domestic groups, HROs lead local populations to substitute alternative strategies for non-violent protest, particularly directing them to pursue more institutionalized strategies for political advocacy.

Underlying both of these theoretical arguments is an understanding that HROs are organizations with finite resources and both local and international goals. ${ }^{38}$ Therefore, HROs want to use their finite resources in such a way as to maximize their effectiveness and achieve their goal, i.e. global improvements in human rights practices. This implies that HROs form cross-border strategies, working beyond their state in ways to aid foreign movements. Given localized knowledge and the need for easy movement of mobilization tools, like cell phones or walkie-talkies, it follows that HROs will use these cross-border strategies within their immediate vicinity. Since resources are finite and the goals are applicable across multiple states, if the HRO sector is well-established in states like Turkey and Thailand, we expect members to be willing to cross borders to aid in mobilization of their neighbors in Syria and Burma, respectively. This could occur as a spontaneous member decision to aid in the efforts of neighboring domestic mobilization attempts or through organized forums such as the Burma Partnership, discussed above.

These expectations are very much in keeping with the overall protest diffusion argument that, once resources have been used within one locale, members can diffuse these resources through the immediate neighborhood. ${ }^{39}$ This, as mentioned, occurred in post-Soviet Eastern Europe. ${ }^{40}$ A similar example of an organized strategy of diffusion was found in Sudan where HROs sent members with resources through the Kenyan-Sudanese border. ${ }^{41}$

As discussed in the Burmese case, HRO resources for non-violent protest take a variety of forms - educational and training materials, discussing the need for non-violent mobilization, as well as material resources such as cell phones, meeting places, radios, or walkie-talkies. All these resources from neighboring HROs can have an effect on

${ }^{37}$ http://pthblog.amnesty.org.uk/break-the-silence-beat-the-junta-2.

${ }^{38}$ Bob 2005; Prakash and Gugerty, 2010.

${ }^{39}$ See Andrews and Biggs 2006. We remain agnostic about the existence of long-distance connectivities. Our review of cases of protest mobilization by HROs did not indicate any clear examples of trade or investment connectivities, for example. Future research on other pathways along which HRO resources are diffused is definitely necessary.

${ }^{40}$ Bunce and Wolchik 1996.

${ }^{41}$ Matthews 2010. 
non-violent protest mobilization in the target country. ${ }^{42}$ The key point here is that, in countries with a dearth of domestic HROs, we may observe a substitution of advocacy by neighborhood HROs that step in to serve the essential role of aiding mobilization for nonviolent protest. Thus, when present, HROs in neighboring countries are expected to amplify domestic non-violent anti-government protests in states with few HROs themselves.

While the Burmese case provides strong anecdotal support for the occurrence of advocacy substitution, a puzzle still remains concerning the effects of neighborhood HROs in countries with well-established HRO and civil society networks. For instance, would HRO presence in Canada or Mexico have the same amplifying effect in the United States as the presence of HROs in Thailand does for Burma? This would go against the idea of HROs using their finite resources efficiently; the United States already has an established HRO sector, and mobilization efforts from neighboring HROs are probably less essential for non-violent protest. If a state has a well-developed HRO sector, it is unlikely that members from neighboring countries will devote their scarce resources and time to the mobilization of domestic non-violent protest in this saturated HRO state. In other words, if coordination resources could be classified as diffusing from an area of comparative strength to an area of comparative need, we would expect less of a role of substitute advocacy in a target state with a strong HRO sector. This reflects a ceiling effect dynamic.

This appears to be the case with anti-war protests in the United States. As Heaney and Rojas's study found, of the 527 organizations that mobilized anti-war protests in the United States from 2007 to 2009, only two were from Canada and just one was from Mexico. ${ }^{43}$ Given the well-established US domestic HRO sector, organizations in the neighborhood do not typically aid mobilization attempts within the country.

In addition to our arguments about the diminishing returns of the effects of neighborhood HROs on non-violent protest, we can expect one additional effect of neighborhood HROs on saturated target states. In those countries with well-established domestic HRO sectors, any effect of neighborhood HROs in these states may be observed through a substitution of strategies. Though most of the focus on domestic opposition movements is on violent and non-violent protest, we know that these are not the only, or even the ideal, strategies for political action. ${ }^{44}$ Opposition activism can take multiple forms, everything from voting to letter writing, lobbying representatives and non-violent and violent protests. Thus, if HRO members cross borders to assist in countries with rich existing HRO sectors, we argue they will turn their attention to other political action strategies, such as encouraging voting for candidates who would make good advocates of rights once elected and directly lobbying those in office. ${ }^{45}$ In other words, at sufficiently high levels of domestic HROs, it is likely that protest mobilization strategies are substituted by alternative forms of political action seen as more effective in achieving the same overall organizational goals. Any observed effect of neighborhood HROs would be likely to be seen in these substituted tactics.

\footnotetext{
${ }^{42}$ It is important to note here that, as Murdie and Bhasin (2011) find, the resources of HROs can still diffuse to groups using violent protest that may also make good use of the same training and communication resources. These resources may have an unintended amplifying effect on domestic violent protest.

43 Heaney and Rojas 2011.

44 Norris 2011; Tarrow 1994.

45 de Vries 2007; Sikkink 2005.
} 
In the case of Canadian HROs encouraging anti-war activism in the United States, we also find some anecdotal evidence in line with this strategy of substitution. For example, instead of aiding in US non-violent protest mobilization, some Canadian HROs are now calling on their own government to arrest US Vice President Cheney and trying to encourage American citizens to do the same within the United States. ${ }^{46}$ Therefore, the impact of neighborhood HROs, in this case, would be to encourage a change in strategy away from the earlier approach of anti-war non-violent protests to a more institutional advocacy strategy.

\section{HYPOTHESES}

What are the empirical implications of this argument? First, in line with the advocacy substitution mechanism, we expect neighborhood HROs to serve as a substitute for domestic HROs in causing more non-violent protests in target states where the domestic HRO sector is not well established. Therefore, under this substitutable advocacy dynamic, we would expect that:

MAIN HYPOTHESIS: Higher levels of neighborhood HRO presence are positively associated with domestic non-violent protest in countries with poor HRO sectors.

It follows that the marginal effects of neighborhood HROs on non-violent protest should be high when the domestic HRO sector is nascent. However, as the domestic HRO sector increases, we should expect less of an impact of neighborhood HROs, who are no longer as critical for mobilizing non-violent protest. Indeed, based on our understanding of HRO goals, the strategies of neighborhood HROs when the domestic HRO sector is large should focus on substituting out of domestic non-violent protest to more insider advocacy tactics, like guiding voters to candidates with strong human rights support and direct lobbying of existing politicians. Thus, if they are still working within the country next door at all, we should expect neighborhood HROs to be encouraging a move away from non-violent protest strategies and to more institutional strategies in those states where such strategies are viable, i.e. states with a large domestic HRO sector. So we would expect:

SUPPLEMENTARY HYPOTHESIS: At sufficiently high levels of domestic HROs, the effect of neighborhood HROs on domestic non-violent protest will be diminished.

By this supplementary or corollary hypothesis, we are arguing that there is a ceiling effect for neighborhood HROs. At sufficiently high numbers of domestic organizations, the effect of neighborhood HROs on non-violent protest diminishes. Any effect of neighborhood HROs in these states would likely been seen in a substitution from non-violent protest strategies to more institutional strategies. These insider institutional strategies would be more readily observed at sufficiently high levels of HRO activity. This could have been argued to have occurred in the case of anti-war protests in the United States, as discussed above. ${ }^{47}$

In outlining these hypotheses, we remain cognizant, however, of the idea that grievances in states with sufficiently high HROs could be somewhat diminished. In other words, neighborhood HROs could have a diminished impact on non-violent protest strategies here because there is less demand for protests overall. ${ }^{48}$

\footnotetext{
46 Lawyers Against War 2011.

47 Heaney and Rojas 2011.

48 Tsutsui and Wotipka 2004.
} 


\section{RESEARCH DESIGN}

In order to test our main hypothesis about substitutable advocacy and our subsequent hypothesis about diminishing returns and substitutable strategies, we implement a measure of non-violent protest and estimate a series of negative binomial models. ${ }^{49}$ Further, to capture the independent variables necessary for testing the above claims, we generate a measure of neighborhood HRO membership through the use of spatialweighting methods. We then interact this indicator with measures of local HRO membership and, as a robustness test, local HRO office or secretariat presence. Further, using country-year data on a sample of 123 countries from 1990 to 2003, we control for several factors found in previous studies to be related to the incidence of protest within a state, as well as for potential spatial and temporal autocorrelation in the level of protest itself. In this section, we discuss the operationalization of the key concepts in the above theoretical argument, as well as the included control variables, before discussing our findings.

\section{Dependent Variable: Non-violent Protest Events}

In order to test our hypotheses appropriately, our dependent variable must (1) capture the level of domestic anti-government protest that occurs within a state in a given year and (2) focus only on non-violent protest activities. Therefore, like Murdie and Bhasin, we use Bhasin's data on the count of all domestic anti-government Non-Violent Protest events that occurred in a given country-year. ${ }^{50}$ This measure relies on data from the Integrated Data for Event Analysis (IDEA) project, which provides information on all daily events in Reuters Global News Service in a "who did what to whom, where, and how' manner. ${ }^{51}$ Bhasin focuses on events in which any domestic actor or group (the 'who') acted non-violently (the 'what' and 'how') against a government agent or office (the 'to whom') in a given domestic locale (the 'where'). ${ }^{52}$ Thus, the variable provides a count of the number of domestic protests, boycotts, sit-ins, or other nonviolent activities directed at the government or a government agent in a given year. ${ }^{53}$

\section{Independent Variables: Local and Neighborhood HRO Presence}

Both of our hypotheses require measures of the presence of HROs domestically and in neighboring states. In the paragraphs that follow, we discuss the measurement of domestic HRO presence and then describe the methods used to convert the domestic measures into a measure of neighborhood HRO presence.

Domestic HRO presence. Our first measure, Domestic HRO Membership, captures the number of HROs that have either members or a volunteer base within a country, using

\footnotetext{
49 We also estimated models implementing a violent protest dependent variable. Our findings are consistent with the expectation that the presence of HROs in a state's neighborhood is unlikely to impact violent protest in the same way that it impacts non-violent protest. These findings are available in Table A1 in our online appendix on the Journal's website.

50 Bhasin 2008; Murdie and Bhasin 2011.

51 Bond et al. 2003; King and Lowe, 2003.

52 Bhasin 2008.

53 A full list of the non-violent protest events included in this measure can be found in Table A2 of our online appendix. Like McCarthy, McPhail, and Smith (1996), we make no distinction between routine and non-routine events and include the possibility of non-violent protest events that originate from government actors to other members of the government.
} 
data provided by Smith and Wiest. ${ }^{54}$ These data were gathered from hard copies of the Yearbook of International Organizations at intervals of every two to three years. Following previous uses of these data, the missing years have been linearly interpolated. ${ }^{55}$ Also similar to previous uses of the data we take the natural log of this measure in order to reduce skewness and the impact of outliers.

Our second measure of domestic HRO presence, Domestic HRO secretariats, captures the number of HROs with a permanent office location within a state, updated from the measure used by Murdie and Bhasin. ${ }^{56}$ Like Smith and Wiest's data, these data are based on information from the Yearbook of International Organizations. ${ }^{57}$ These data are quite distinct from those on HRO membership. The presence of an office represents a much greater and more lasting investment in a state by the organization, compared with membership, whose location is likely to be dictated by the members themselves.

Neighborhood HRO presence. Our theory posits that, in the absence of a local HRO presence, HRO members from neighboring states are capable of substituting their activities for those of the missing domestic organizations. Thus, we need a way of measuring the degree to which HROs are active in states that are near enough to the at-need state and thus most able to provide aid. We rely on spatial-weighting techniques drawn from the spatial econometrics literature to generate a neighborhood average of our HRO membership measure. ${ }^{58}$

In particular, we suggest that, in order for HRO presence to affect the level of mobilization in surrounding states that lack such a presence, persons and materials must be capable of traveling to the at-need state. Previous research has indicated that it is likely that neighboring $\mathrm{HRO}$ presence is only capable of exerting an effect over a relatively short distance. ${ }^{59}$ Additionally, of our relevant HRO measures, it is HRO membership, as opposed to HRO secretariats, in neighboring states that would be capable of traveling to aid in mobilization. In other words, though domestic HRO secretariats may be important for mobilization, we posit that neighboring HRO secretariats would not have the same cross-border effects. Thus, we follow this previous work and define the relevant neighborhood for our analyses as those states whose minimum distance from the borders of the state concerned is less than $50 \mathrm{~km}$. Treating all neighbors located within this distance as contiguous to the referent state, we generate a row-standardized connectivity matrix, $\mathbf{W}$, which is used to weight each of our HRO presence variables on the basis of, first, whether or not the minimum distance between the borders of states $i$ and $j$ is less than $50 \mathrm{~km}$ and, second, the total number of states whose borders are within $50 \mathrm{~km}$ of state $i$. Therefore,

$$
\mathbf{W}_{i j}=\frac{c_{i j}}{\sum_{j=1}^{n} c_{i j}},
$$

where $c_{i j}$ equals 1 if the minimum distance between states $i$ and $j$ is less than $50 \mathrm{~km}$ and 0 if it is not. Given that international borders may change from year to year, $\mathbf{W}$ varies across time to match these changes.

${ }^{54}$ Smith and Wiest 2005.

55 Bell, Clay, and Murdie 2012; Murdie and Bhasin 2011; Murdie and Davis 2012.

${ }^{56}$ Murdie and Bhasin 2011.

${ }^{57}$ UIA, 2008/2009.

${ }^{58}$ See Beck, Gleditsch, and Beardsley 2006; Buhaug and Gleditsch 2008; Franzese and Hays 2007.

${ }^{59}$ Bell, Clay, and Murdie 2012. 
Finally, in order to create our measure of Neighborhood HRO Membership, we multiply W by the corresponding data vector of the domestic HRO membership measure. Thus, this measure provides the average level of HRO membership in states that are within $50 \mathrm{~km}$ of the referent state $i$, whichever state that may be. For instance, throughout our time period, the United States has two neighbors within $50 \mathrm{~km}$ of its borders, i.e. Mexico and Canada. As such, the Neighborhood HRO Membership value for the United States should be equal to the number of HROs with members in Canada plus the number of HROs with members in Mexico, divided by two. ${ }^{60}$ As a robustness test and for a necessary control, we also create a neighborhood-weighted measure of the HRO secretariat, Neighborhood HRO Secretariat.

Data for creating $\mathbf{W}$ were obtained by creating adjacency matrices for each year in our analyses using the CShapes package in $\mathrm{R}^{61}$ Further, the connectivity matrix was rowstandardized using the spatwmat command in Stata. ${ }^{62}$ Finally, as we are primarily concerned with the ability of neighboring HROs to affect local mobilization, we exclude all states with no neighbors from our analyses.

\section{Control Variables and Model Specification}

Beyond our variables of primary theoretical interest, previous research has found several factors that contribute to the likelihood of anti-government protest and we must control for these in our analyses. First, it is highly likely that the human rights practices of states are both linked to the likelihood of protest, as well as the activities of HROs. ${ }^{63}$ Thus we control for government respect for human rights using the CIRI Human Rights Data Project's Physical Integrity Rights Index, which sums four measures of the degree to which governments respect their citizens' rights not to be tortured, extrajudicially executed, politically imprisoned, and disappeared, respectively. ${ }^{64}$ Each of these individual measures varies from 0 to 2 ; the physical integrity rights index thus varies from 0 to 8 , with higher scores representing greater respect for human rights. Likewise, previous work has also demonstrated both that respect for physical integrity in one state is likely to lead to improved human rights practices in neighboring states and that persons are likely to become increasingly dissatisfied with their own state's human rights practices when exposed to the existence of better practices elsewhere. ${ }^{65}$ Therefore, we also control for the Neighborhood Physical Integrity Rights Index, which is generated via the same spatialweighting method as that used for the neighborhood HRO membership variable.

Previous research has demonstrated that democracies are less likely to experience various forms of anti-government activity; we posit that a similar relationship is likely to

${ }^{60}$ As suggested by Beck, Gleditsch, and Beardsley (2006), we recognize that other state connectivities may also lead to some of the dynamics theorized here, particularly connectivities that reduce the cost of transferring resources from one state to another. However, robustness tests utilizing measures of HRO membership weighted by total trade between states, in one case, and colonial history in another found no relationship between these variables and the occurrence of non-violent protest, while the findings for the effects of the neighborhood-based measure discussed here were robust in comparison. These robustness tests can be found in Table A3 of the online appendix. We hope future research will investigate the importance of other alternative connectivities in the processes discussed in this study.

${ }_{61}^{61}$ Weidmann and Gleditsch 2010; Weidmann, Kuse, and Gleditsch 2010.

${ }^{62}$ Pisati 2001.

${ }^{63}$ Carey 2006; Murdie and Bhasin 2011; Regan and Norton 2005.

${ }^{64}$ Cingranelli and Richards 2010.

${ }^{65}$ Bell, Clay, and Murdie 2012; Davis, Murdie, and Garnett 2012. 
exist when looking at non-violent protest. ${ }^{66}$ In order to gauge the effect of regime type on the occurrence of protest, we use the Polity score, which varies from -10 (most autocratic) to 10 (most democratic). ${ }^{67}$ Likewise, previous work has linked economic development to the likelihood of certain types of antigovernment activity. ${ }^{68}$ As such, we control for the natural $\log$ of GDP per capita in constant US dollars, as recorded in the World Bank's World Development Indicators. ${ }^{69}$ As states with larger populations are both more likely to engage in repression and more likely to experience certain forms of antigovernment activity we also control for the natural log of population. Finally, to control for the close relationship between war and antigovernment activity, we include a control that equals 1 if the state is experiencing either interstate or intrastate war within its borders and 0 if it is not. These data are based on information from the UCDP/PRIO Armed Conflict Databank. ${ }^{70}$

In order to account for any differences in non-violent protest counts that may arise from differing levels of news coverage among countries, we control for the natural log of total IDEACoverage, i.e. the logged total number of domestic events recorded in the IDEA database for a given country-year. Furthermore, as previous research has found a significant positive relationship between violent protest and non-violent protest, we control for the occurrence of the violent protest in each model. ${ }^{71}$

As our theory explicitly acknowledges the degree to which many outcomes and events cluster in geographic space as well as time, we control for temporal and spatial autocorrelation in all models. Our control for temporal autocorrelation is a one-year lag of the dependent variable. We control for spatial autocorrelation by including a spatially-weighted average of the dependent variable, generated by the same spatial-weighting method as that used for the neighborhood HRO membership variable, to create a measure of Neighborhood Non-Violent Protest. In order to reduce the potential for endogeneity, all independent variables are lagged one year. Finally, to account properly for over dispersion and positive contagion in the counts of non-violent protests, we use a negative binomial model with robust standard errors. ${ }^{72}$

\section{Additional Tests: Ceiling Effect}

To evaluate the main hypothesis, we expect to see a positive coefficient on the constituent terms Domestic HRO Membership (or, as included in the robustness check, Domestic HRO Secretariat) and the Neighborhood HRO membership. We also expect, reflecting the idea of a ceiling effect, that the interaction terms created from these constituent parts should have a negative and statistically significant effect on nonviolent protest. Remember that our theory implies that at sufficiently high levels of Domestic HROs, we should see Neighborhood HROs have a diminishing impact on non-violent protest. This is the key insight we seek to evaluate in the supplemental hypothesis. This, we suggest, could be both due to a substitution of strategies or could be due to fewer overall grievances.

The basic insight of the supplemental hypothesis can be, at its face, evaluated through examining the marginal effects of Neighborhood HRO Membership at sufficiently high levels of Domestic HRO Membership; at these high levels, the marginal effects should be diminished.

${ }^{66}$ See Hegre et al. 2001; Li, 2005; Regan and Bell 2010.

${ }^{67}$ Marshall and Jaggers 2009.

${ }^{68}$ Elbadawi and Sambanis 2002; Hegre et al. 2001; Regan and Norton 2005.

${ }^{69}$ World Development Indicators 2010.

${ }^{70} \mathrm{UCDP} / \mathrm{PRIO} 2008$.

${ }^{71}$ Murdie and Bhasin 2011.

${ }^{72}$ Cameron and Trivedi 1998; Long 1997. 
However, we also sought to find a way to evaluate what makes these 'sufficiently' high Domestic HRO Membership countries different and to what extent these reflect different political repertoires or political opportunity structures and differences in actual or perceived grievances. We conduct a series of difference of mean t-tests to evaluate these hypotheses. In particular, we attempt to discern whether there are systematic differences between states that have a sufficiently vibrant domestic HRO sector and those that do not. These are the states where we expect that non-violent protest will be less necessary for political change, making it less likely that increases in neighboring HROs amplify the level of non-violent protest. Part of where that threshold comes from is determined by the results from conducting tests of the main hypothesis and is discussed more fully below.

In order to examine whether there are other pathways through which these states can produce political change and whether the populations in these states are less likely to be aggrieved, we use a series of variables to capture these two concepts. To test whether there are systematic differences in the pathways for political change, we look at whether there are differences in the democracy (Polity) levels between the two groups of states. We also use data from the World Values Survey to identify the proportion of the population that self identifies as having signed a petition. ${ }^{73}$ The idea here is that states with an especially active HRO sector will be more likely to rely on these more institutionalized tools, as opposed to taking to the streets through protest.

To identify whether these states with more domestic HROs have populations that have systematically fewer grievances we look at differences in the physical integrity rights between the two groups of states, differences in GDP per capita, and whether there are differences in how the populations perceive their human rights treatment. The first two measures come from the same datasets used for testing the main hypothesis. The third variable is also measured from the World Values Survey data and it comes from a question that asks whether respondents feel that their human rights are adequately respected. ${ }^{74}$ Again, our expectation is that states with larger domestic HRO sectors should have fewer grievances. The results of these tests follow our discussion of the main results.

\section{RESULTS AND DISCUSSION}

In this section we start by testing our core hypothesis, that an increasing presence of HRO members in neighboring states, when there is a lack of domestic HRO members on the ground, leads to an increase in the level of non-violent protest within a state. Second, we examine the difference of means $t$-tests to flesh out whether there are certain types of states that are unlikely to experience the additional protest that comes with high levels of both domestic and neighboring HROs. These are the states where citizens have alternative pathways available for political change.

\section{Main Hypothesis}

Table 1 presents the results from the negative binomial regression model. Again, the interaction term between domestic HRO membership and neighborhood HRO membership allows us to draw inferences about whether neighboring HROs fill the advocacy vacuum left

\footnotetext{
73 World Values Group Research Study Group, 1980-2008.

74 The actual question asked on the World Values Survey is: How much respect is there for individual human rights nowadays (in our country)? Do you feel: 1 'There is a lot of respect for individual human rights'. 2 'There is some respect'. 3 'There is not much respect'. 4 'There is no respect at all'.
} 
TA B LE 1 The Impact of Neighborhood HROs on Non-violent Protest: Negative Binomial Model with Robust Standard Errors, 1990-2003

\begin{tabular}{|c|c|}
\hline Variables & $\begin{array}{c}\text { Coefficient } \\
\text { (Standard Error) }\end{array}$ \\
\hline HRO Secretariat $_{t-1}$ & $\begin{array}{l}0.0567 * * \\
(0.024)\end{array}$ \\
\hline Neighborhood HRO Secretariat ${ }_{t-1}$ & $\begin{array}{l}0.0217^{* * *} \\
(0.006)\end{array}$ \\
\hline HRO Member $(\ln )_{t-1}$ & $\begin{array}{l}0.6613^{* * * *} \\
(0.181)\end{array}$ \\
\hline Neighborhood HRO Member $(\ln )_{t-1}$ & $\begin{array}{l}0.6629^{* * *} \\
(0.211)\end{array}$ \\
\hline HRO Member $(\ln ) \times$ Neighborhood HRO Member $(\ln )_{t-1}$ & $\begin{array}{l}-0.2314 * * * \\
(0.058)\end{array}$ \\
\hline HRO Secretariat $(\ln ) \times$ Neighborhood HRO Member $(\ln )_{t-1}$ & $\begin{array}{l}-0.0135^{* *} \\
(0.006)\end{array}$ \\
\hline Violent Protest $_{t-1}$ & $\begin{array}{l}0.0019^{* *} \\
(0.001)\end{array}$ \\
\hline Non-Violent Protest $_{t-1}$ & $\begin{array}{l}0.0048^{* * *} \\
(0.001)\end{array}$ \\
\hline Neighborhood Non-Violent Protest $_{t-1}$ & $\begin{array}{l}-0.0039 * * \\
(0.002)\end{array}$ \\
\hline Neighborhood Physical Integrity Rights Index $(\mathrm{CIRI})_{t-1}$ & $\begin{array}{c}0.0194 \\
(0.016)\end{array}$ \\
\hline Physical Integrity Rights Index (CIRI) $)_{t-1}$ & $\begin{array}{l}-0.0565 * * * \\
(0.017)\end{array}$ \\
\hline Population $(\ln )_{t-1}$ & $\begin{array}{l}0.2353^{* * *} \\
(0.030)\end{array}$ \\
\hline GDP per capita $(\ln )_{t-1}$ & $\begin{array}{r}0.0297 \\
(0.028)\end{array}$ \\
\hline War (Interstate or Intrastate) $)_{t-1}$ & $\begin{array}{l}-0.1926^{*} \\
(0.108)\end{array}$ \\
\hline Polity Score $(-10 \text { to } 10)_{t-1}$ & $\begin{array}{l}0.0145^{* * *} \\
(0.005)\end{array}$ \\
\hline IDEA Coverage $(\ln )_{t-1}$ & $\begin{array}{l}0.4872 * * * \\
(0.034)\end{array}$ \\
\hline Constant & $\begin{array}{l}-7.7720^{* * *} \\
(0.834)\end{array}$ \\
\hline In alpha & $\begin{array}{l}-0.9066^{* * *} \\
(0.077)\end{array}$ \\
\hline Observations & 1,546 \\
\hline
\end{tabular}

Notes: Robust standard errors in parentheses. ${ }^{* * *} p<0.01,{ }^{* *} p<0.05,{ }^{*} p<0.1$ (two-tailed).

by a lack of domestic HROs. As a robustness check of this idea, we also include a variable for domestic HRO secretariat office presence and an interaction between that variable and neighboring HRO membership. We also include a neighborhood variable for HRO secretariat presence.

As shown in Table 1, the results provide support for our core hypothesis, i.e. that the presence of $\mathrm{HRO}$ members in neighboring states increases the level of non-violent protest when there is a sufficiently low domestic presence of HRO members or HRO secretariats. The way in which the domestic and neighborhood advocacy pathways substitute for each other is demonstrated by examining the coefficients on the constituent variables of domestic HRO membership (or HRO secretariat) and neighborhood HRO membership and the interaction between them. Consistent with prior work that uses this dependent variable, the presence of 


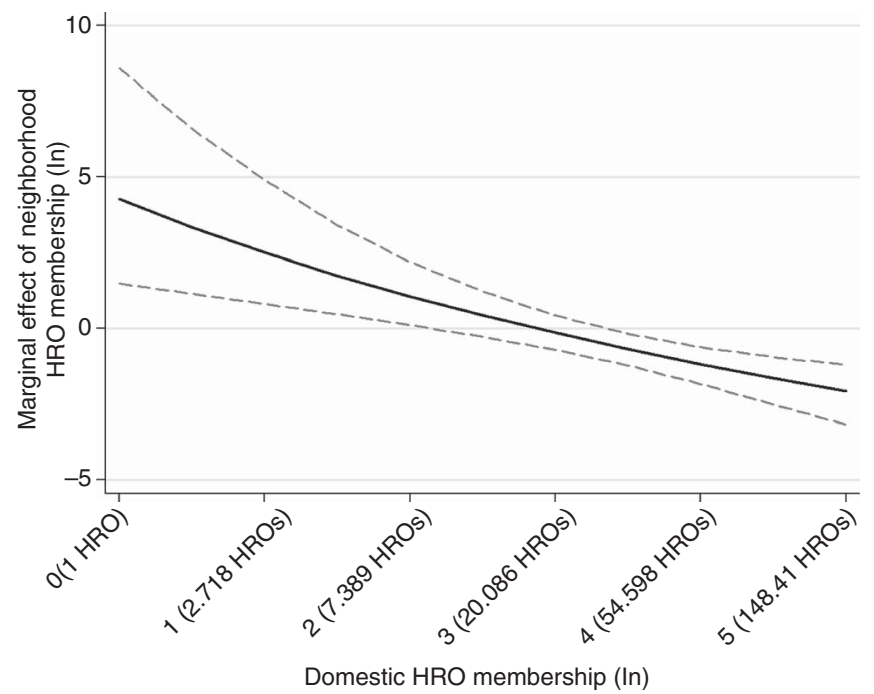

Fig. 1. The conditional effect of neighborhood HRO members

domestic HROs increases the level of non-violent political protest. ${ }^{75}$ The coefficient for the neighboring $\mathrm{HRO}$ variable is also positive and statistically significant, indicating that when the domestic HRO presence is at zero, the effect of neighboring HROs is positive. The negative coefficient on the interaction term provides evidence in support of our secondary hypothesis that, as domestic HRO presence increases, the effect of neighboring HROs is diminished.

The statistically significant results on the control variables are largely consistent with previous findings. The novel variable that measures neighborhood non-violent protest is negative and statistically significant, suggesting that, after accounting for HRO activities, states in neighborhoods with a lot of non-violent protest are less likely to experience non-violent protest themselves. Neighborhood human rights levels are positive, but not significant, suggesting that, if neighborhood human rights practices affect non-violent

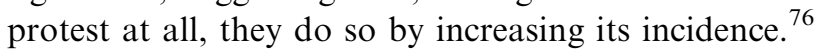

Figure 1 shows the marginal effect of neighboring HRO members on the count of nonviolent protest at varying levels of domestic HRO membership presence. This figure shows that, at sufficiently low levels of domestic HRO member presence, neighboring HROs fill the void left by the absence of domestic organizations, and as a result they increase the level of non-violent protest. It appears that as a state has sufficiently high numbers of domestic HRO members (a value of 3.5 or thirty-three HROs with members in the state), the effect of an additional neighboring HRO member diminishes. This is consistent with our secondary hypothesis. In states that are so heavily saturated with a

${ }^{75}$ Murdie and Bhasin 2011.

76 This is unsurprising, given previous research that suggests that human rights-related grievances are likely to increase as persons become more aware of better practices elsewhere. See Davis, Murdie, and Garnett 2012. Thus, exposure to better practices in neighboring states informs persons of their own state's relative repressiveness, leading to increased grievance and, in our models, increased non-violent protest. Furthermore, this provides evidence of one mechanism by which improvements in human rights practices may be predicted by high respect for human rights in neighboring states. See Bell, Clay, and Murdie 2012. 
broad based advocacy network and rich civil society, protest is actually less necessary. There are other substitutable strategies that these organizations can engage in to pursue political change. If this is the case, we should expect this category of states to be more democratic, to have better human rights records, and to be states that provide grievance expression mechanisms other than protest.

Of course, we are also interested in the result on the interaction term between domestic HRO secretariats and neighboring HRO members. This interaction terms allows for inferences to be drawn regarding whether neighboring member presence can also substitute for the lack of presence of domestic secretariat offices. The coefficient on the interaction term is also negative and statistically significant, consistent with our expectation that the presence of HRO members in neighboring states will produce diminishing returns in the presence of an active domestic HRO secretariat presence. ${ }^{77}$

Overall, these findings allow for the inference that, in general, HROs increase the level of non-violent political protest in a state. Consistent with Murdie and Bhasin, when there is a vibrant HRO sector inside a state, there will be greater levels of non-violent political protest. ${ }^{78}$ What we show here is that HROs can increase domestic protest even in the absence of an active domestic HRO sector. When there is a deficit of local organizations, HRO members located in neighboring states can fill the void and spur greater non-violent protest. When there are sufficient numbers of domestic HROs, however, neighboring HROs do not amplify non-violent protest.

\section{Supplemental Hypothesis: Additional Tests}

To evaluate the supplemental hypothesis concerning the ceiling effect and a substitution of strategies more thoroughly, we want to know whether there are systematic differences between the states that have high domestic HRO membership and those that do not. The model in Table 1 indicates that at these high levels of domestic HRO membership, the effect of an increase in neighboring HRO presence actually decreases the level of nonviolent protest. This is consistent with our theoretical claim underlying the supplemental hypothesis that these types of states will have alternative pathways through which political change can occur and are also likely to experience fewer grievances. As a further check on this claim, we provide two sets of tests here.

First, from Figure 1, it is apparent that when the logged HRO domestic membership measure equals or exceeds 3.5 , i.e. when there are more than thirty-three HROs with domestically-based members, additional neighboring HRO members serve to decrease the level of non-violent protest. We first examine whether these states that are above the 3.5 threshold on the measure of domestic HRO presence have statistically significantly higher levels of democracy, as measured by the -10 to +10 Polity scale. If they do, this provides some support for the hypothesis that these kinds of states have alternative pathways to petition government for change. This does not mean that we will never see protest in these states, but that HROs and individuals have other tools in their toolbox to choose from and that the addition of neighboring HROs could make them more likely to use these institutionalized tools. We find that the difference of means in Polity scores between the states below the 3.5 threshold on domestic HRO membership and those

\footnotetext{
77 Marginal effects graphs of this interaction are available in Figure A1 of the online appendix and reflect, again, the basic logic shown in Figure 1 concerning the substitution of advocacy.

78 Murdie and Bhasin 2011.
} 
TA B LE 2 T-Tests: Differences in Strategies and Grievances between Countries with High HRO Membership and Countries without High HRO Membership

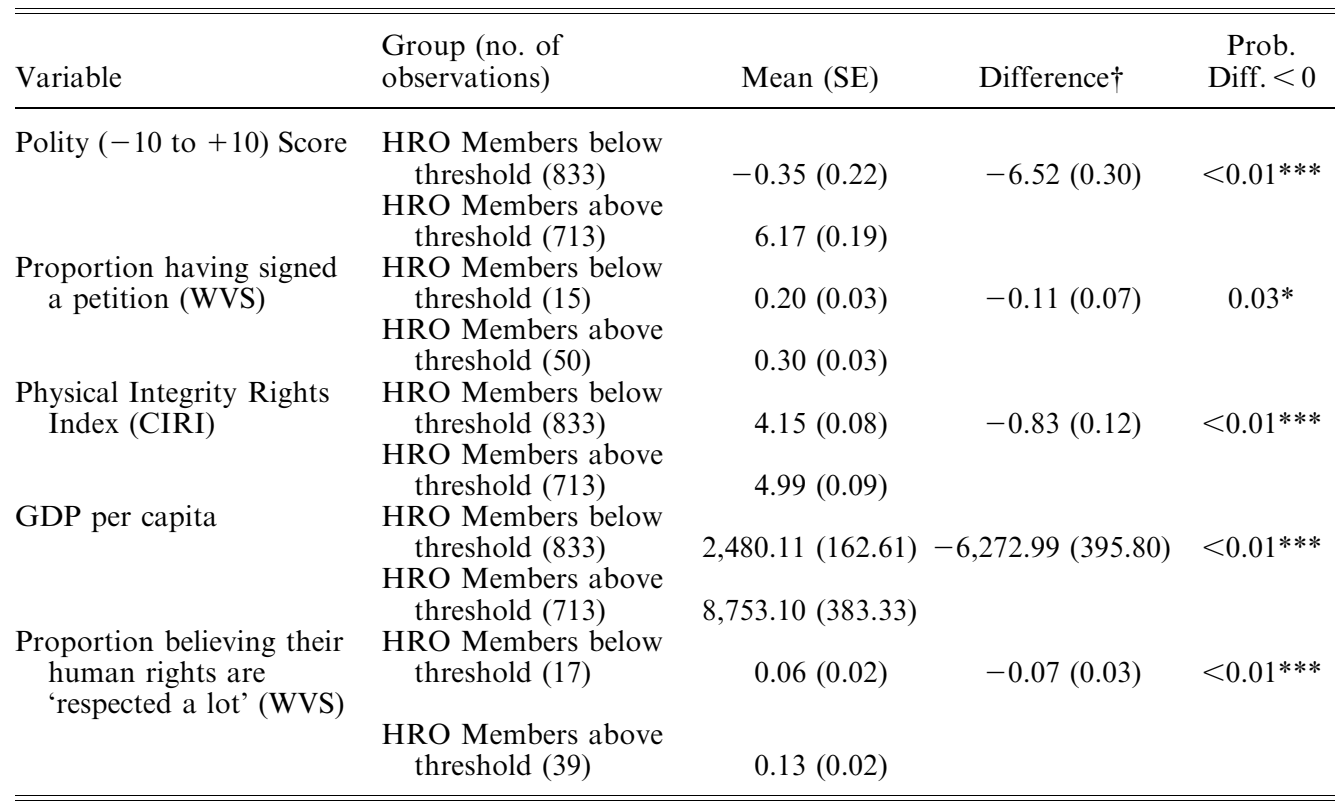

Notes: $\uparrow$ Low HRO Group Mean minus High HRO Group Mean. WVS = World Values Survey.

above is statistically significant, with a mean of 6.16 for those above 3.5 and a mean of -0.35 for those below the 3.5 threshold (see Table 2).

We also use the World Values Survey data described above to test this hypothesis more rigorously. The sample is again split between those states above 3.5 on domestic HRO membership (ln) and those below. A difference of means test is conducted to determine whether the proportion of individuals within a state that sign petitions is different for the two groups of observations. The test suggests that those states below the threshold have statistically significantly fewer people self-reporting as having signed a petition than those states that are above the threshold. In the states with fewer HROs the average proportion to report having signed a petition is 19.6 percent; in the states with more than the threshold on the domestic HRO measure the proportion is 30.2 percent. This serves to demonstrate that the states that are above this threshold on domestic HRO presence can turn towards other tactics for policy change that might directly engage policy makers as opposed to non-violent protests. This is consistent with the finding that the effect of neighboring HROs diminishes at sufficiently high levels of domestic HRO presence.

The second set of tests gauge whether there are likely to be fewer grievances in the states that are above this 3.5 threshold on the domestic HRO member variable. This will further help to explain why the effect of neighboring HRO members diminishes when a strong domestic HRO sector exists. The first test compares the mean on physical integrity rights between the cases above and below the 3.5 threshold. The cases above the 3.5 threshold have an average physical integrity rights score of 4.15 and the cases below the 3.5 threshold have an average score of 4.98. This difference is statistically significant and suggests that individuals who live in these states with a greater number of HROs are less likely to experience repression. 
In addition, the per capita incomes between these two groups of states are substantially different. The difference between the two groups is $\$ 6,272$ and is statistically significant. Economic conditions are stronger in the states with greater numbers of domestic HRO members. This general higher economic performance provides fewer reasons to protest in the states with many domestic HRO members.

The next test also uses the World Values Survey data and compares the level of respondents that believe their human rights are 'respected a lot' by their government. For the states above 3.5 the proportion of respondents answering that their human rights are respected 'a lot' is 13.4 percent, for the states in the sample below 3.5 the mean is 6.1 percent. This difference is statistically significant. This result provides evidence that individuals in these states with more domestic HROs are less likely to feel as though their human rights are being violated and to be aggrieved.

Overall the findings here provide evidence to help bolster this claim that the states with the most vibrant HRO sectors are going to have more tools to choose from for enacting policy change and fewer actual grievances towards their governments. The individuals in these states are more likely to have democratic institutions to engender policy change. They are also less likely to have their human rights violated by the government, have higher per capita income, and perceive a higher level of respect for their human rights. This should all result in fewer grievances against the government and also less non-violent protest.

\section{CONCLUSION}

This work makes both empirical and theoretical contributions to the existing literature. Theoretically, it provides an important piece of the puzzle surrounding the work of HROs. It sets clear expectations for the conditions under which HROs influence nonviolent protest across borders. We find that neighborhood HRO members can aid their brothers-in-arms in mobilization attempts.

This finding has import for both scholars and practitioners. For scholars, this is further evidence in support of the global reach of HROs. HROs have goals in groups of states and activities that cross state boundaries reflect these goals. Practitioners can learn from HROs that are already engaging in these cross-border activities and mirror these successful strategies elsewhere. This bodes well particularly for those interested in aiding domestic mobilization in countries where domestic HRO presence has been underdeveloped historically, such as Syria or Burma. Instead of having to depend on local members or offices of HROs to aid in mobilization attempts, we find that neighborhood HRO members can serve as powerful substitutes for the advocacy mobilization previously thought to result from domestic HROs alone.

If domestic HRO members are flourishing, we find that neighborhood HROs have a ceiling effect: they do not increase nonviolent protest. It may be that any efforts of neighborhood HROs in these states work to substitute strategies away from protest and to more institutionalized advocacy strategies. These findings are consistent with a view of HROs as organizations that have goals across borders and that work in a strategic way to achieve these goals most efficiently.

Previous work has shown that neighboring HRO members improve the human rights records of states. ${ }^{79}$ This work helps to elaborate the role of these organizations in enacting political change inside of neighboring states. The results here provide additional evidence

${ }^{79}$ Bell, Clay, and Murdie 2012. 
that HROs engage in activities in states other than those in which they were originally based, but also that HROs use their resources efficiently through varied mobilization strategies on the ground.

More broadly, this research challenges conventional notions of how HROs and other transnational non-state actors affect domestic politics. ${ }^{80}$ Instead of needing to be involved directly within a state, transnational actors like HROs can still be powerful conduits for domestic anti-government behavior even without having a formal presence within the country. In short, instead of waiting for the fight to develop organically from the domestic population of a state, neighborhood HROs are willing to take the fight to them. This finding reiterates the potential of international actors to implement change in the domestic realm.

\section{LIST OF REFERENCES}

Al-Assad, Asma. 2010. Speech given at Conference on the Emerging Role of Civil Society in Development, Damascus, 23 December.

Andrews, Kenneth T., and Michael Biggs. 2006. The Dynamics of Protest Diffusion: Movement Organizations, Social Networks, and News Media in the 1960 Sit-ins. American Sociological Review 71 (October): 752-77.

Aldashev, Thierry, and Gani Verdier. 2010. Goodwill Bazaar: NGO Competition and Giving to Development. Journal of Development Economics 91 (1):48-63.

Beck, Nathaniel, Kristian Skrede Gleditsch, and Kyle Beardsley. 2006. Space is More than Geography: Using Spatial Econometrics in the Study of Political Economy. International Studies Quarterly 50:27-44.

Beer, Michael A. 1999. Violent and Nonviolent Struggle in Burma: Is a Unified Strategy Workable? Pp. 174-85 in Nonviolent Social Movements: A Geographical Perspective, edited by Stephen Zunes, Sarah Beth Asher, and Lester Asher. Oxford: Blackwell.

Bell, Sam R., K. Chad Clay, and Amanda Murdie. 2012. Neighborhood Watch: Spatial Effects of Human Rights INGOs. Journal of Politics 74 (2):1-16.

Bhasin, Tavishi. 2008. Democracy and Dissent: Explaining Protest and State Response. Doctoral dissertation. Emory University, Atlanta.

Bob, Clifford. 2005. The Marketing of Rebellion: Insurgents, Media, and International Activism. Cambridge: Cambridge University Press.

Bond, Doug., Joe Bond, Churl Oh, J. Craig Jenkins, and Charles Lewis Taylor. 2003. Integrated Data For Events Analysis (IDEA): An Event Typology For Automated Events Data Development. Journal of Peace Research 40 (6):733-45.

Boulding, Carew E. 2010. NGOs and Political Participation in Weak Democracies: Subnational Evidence on Protest and Voter Turnout from Bolivia. Journal of Politics 72 (2):456-68.

Buhaug, Halvard, and Kristian Skrede Gleditsch. 2008. Contagion or Confusion? Why Conflicts Cluster in Space. International Studies Quarterly 52 (2):215-33.

Bunce, Valerie, and Sharon L. Wolchik. 2006. Favorable Conditions and Electoral Revolutions. Journal of Democracy 17 (4):5-18.

Cingranelli, David L., and David L. Richards. 1999. Respect for Human Rights after the End of the Cold War. Journal of Peace Research 36 (5):511-34.

- 2010. The Cingranelli and Richards (CIRI) Human Rights Data Project. Human Rights Quarterly 32 (2):401-24.

Cameron, A. Colin, and Pravin K. Trivedi 1998. Regression Analysis of Count Data. Econometric Society Monograph No.30, Cambridge: Cambridge University Press.

Carey, Sabine C. 2006. The Dynamic Relationship between Protest and Repression. Political Research Quarterly 59 (1):1-11.

${ }^{80}$ Gourevitch 1978. 
Cooley, Alexander, and James Ron. 2002. The NGO Scramble: Organizational Insecurity and the Political Economy of Transnational Action. International Security 27 (1):3-39.

Davis, David R., Murdie Amanda, and Garnett Coty. 2012. Makers and Shapers: Human Rights INGOs and Public Opinion. Human Rights Quarterly 34 (1):199-224.

de Vries, Helma. 2007. Insider and Outsiders: Global Social Movements, Party Politics, and Democracy in Europe and North America. Doctoral dissertation. University of Maryland.

EEAS. 2011. Delegation of the European Union to Syria. Available from http://eeas.europa.eu/ delegations/syria/eu_syria/tech_financial_cooperation/civil_society/index_en.htm.

Elbadawi, I., and N. Sambanis. 2002. How Much War Will We See? Explaining the Prevalence of Civil War. Journal of Conflict Resolution 46 (3):307-34.

Franklin, James C. 2008. Shame on You: The Impact of Human Rights Criticism on Political Repression in Latin America. International Studies Quarterly 52 (1):187-211.

Franzese, Robert J. Jr., and Jude C. Hays. 2007. Spatial Econometric Models of Cross-Sectional Interdepedence in Political Science Panel and Time-Series-Cross-Section Data. Political Analysis 15 (2):140-64.

Gourevitch, Peter. 1978. The Second Image Reversed: The International Sources of Domestic Politics. International Organization 32 (4):881-912.

Haines, Herbert H. 1984. Black Radicalization and the Funding of Civil Rights: 1957-1970. Social Problems 32 (1):31-43.

Heaney, Michael T., and Fabio Rojas. 2011. Hybrid Activism: Social Movement Mobilization in a Multi-Movement Environment. Paper presented at the Annual Meeting of the American Political Science Association, Seattle, Washington.

Hegre, Håvard, Tanja Ellingsen, Scott Gates, and Nils Petter Gleditsch. 2001. Towards a Democratic Civil Peace? Democracy, Political Change, and Civil War 1816-1992. American Political Science Review 95 (1):33-48.

Human Rights Watch. 2011. We've Never Seen Such Horror: Crimes against Humanity by Syrian Security Forces. Available from www.hrw.org.

ICNL. 2009. Global Trends in NGO Law. International Center for Not for Profit Law. 1(2):May. Available from http://www.icnl.org/knowledge/globaltrends/glotrends1-1.htm.

Keck, Margaret E., and Kathryn Sikkink. 1998. Activists beyond Borders: Advocacy Networks in International Politics. Ithaca, N.Y.: Cornell University Press.

Kriesi, Hanspeter. 1996. The Organizational Structure of New Social Movements in a Political Context. Pp. 152-84 in Comparative Perspectives on Social Movements: Political Opportunities, Mobilizing, Structures, and Cultural Framings, edited by Doug McAdam, John D. McCarthy, and Mayer N. Zald. Cambridge: Cambridge University Press.

Lawyers Against War. 2011. Press release on Cheney. 25 September.

Li, Quan. 2005. Does Democracy Promote or Reduce Transnational Terrorist Incidents? Journal of Conflict Resolution 49 (2):278-97.

Long, J.S. 1997. Regression Models for Categorical and Limited Dependent Variables. Thousand Oaks, Calif.: Sage.

Marshall, Monty, and Keith Jaggers. 2009. Polity IV Project. Center for Systemic Peace. Available from http://www.systemicpeace.org/polity/polity4.htm, accessed 28 September 2012.

Matthews, David 2010. A man with a mission. Washington Post Sunday Magazine. W14. 29 January.

McAdam, Doug, Sidney Tarrow, and Charles Tilly. 2001. Dynamics of Contention. Cambridge: Cambridge University Press.

McCarthy, John D., Clark McPhail, and Jackie Smith. 1996. Images of Protest: Dimensions of Selection Bias in Media Coverage of Washington Demonstrations, 1982 and 1991. American Sociological Review 61 (3):478-99.

Murdie, Amanda, and Tavishi Bhasin. 2011. Aiding and Abetting: Human Rights INGOs and Domestic Protest. Journal of Conflict Resolution 55 (2):163-91.

Murdie, Amanda, and David Davis. 2012. Shaming and Blaming: Using Events Data to Assess the Impact of Human Rights INGOs. International Studies Quarterly 56 (1):1-16. 
Norris, Pippa. 2002. Democratic Phoenix: Reinventing Political Activism. Cambridge: Cambridge University Press.

—. 2011. Democratic Deficit: Critical Citizens Revisited. Cambridge: Cambridge University Press. Pisati, Maurizio. 2001. Tools for Spatial Analysis. Stata Technical Bulletin 60 (March) 21-37.

Prakash, Aseem, and Mary Kay Gugerty. eds. 2010. Advocacy Organizations and Collective Action. Cambridge: Cambridge University Press.

Regan, Patrick M., and Sam R. Bell. 2010. Changing Lanes or Stuck in the Middle: Why Are Anocracies More Prone to Civil Wars? Political Research Quarterly 63 (4):747-59.

Regan, Patrick M., and Daniel Norton. 2005. Protest, Rebellion, and the Onset of Civil Wars. Journal of Conflict Resolution 49 (3):1-18.

Risse, Thomas, Stephen C. Ropp, and Kathryn Sikkink. eds. 1999. The Power of Human Rights: International Norms and Domestic Change. Cambridge: Cambridge University Press.

Ron, James, Howard Ramos, and Kathleen Rodgers. 2005. Transnational Informational Politics: NGO Human Rights Reporting, 1986-2000. International Studies Quarterly 49:557-87.

Schmitz, Hans Peter. 2002. From Lobbying to Shaming: The Evolution of Human Rights Activism since the 1940s. Paper presented at the International Studies Association Meeting, New Orleans.

Schock, Kurt. 2004. Unarmed Insurrections: People Power Movements in Nondemocracies. Minneapolis: University of Minnesota Press.

Sikkink, Kathryn. 2005. Patterns of Dynamic Multilevel Governance and the Insider-Outsider Coalition. Pp. 151-74 in Transnational Protest and Global Activism, edited by Donatella della Porta and Sidney Tarrow. New York: Rowman and Littlefield.

Smith, Jackie, and Dawn Wiest. 2005. The Uneven Geography of Global Civil Society: National and Global Influences on Transnational Association. Social Forces 84 (2):621-52.

Stephan, Maria J., and Erica Chenoweth. 2008. Why Civil Resistance Works: The Strategic Logic of Nonviolent Conflict. International Security 33 (1):7-44.

Tarrow, Sidney. 1994. Power in Movement: Collective Action, Social Movements and Politics. Cambridge: Cambridge University Press.

Taylor, Rupert. 2002. South Africa: The Role of Peace and Conflict Resolution Organizations in the Struggle against Apartheid. Pp. 69-93 in Mobilizing for Peace: Conflict Resolution in Northern Ireland, Israel/Palestine, and South Africa, edited by Benjamin Gidron, Stanley Katz, and Yeheskel Hasenfeld. Oxford: Oxford University Press.

Tsutsui, Kiyoteru, and Christine M. Wotipka. 2004. Global Civil Society and the International Human Rights Movement: Citizen Participation in Human Rights International Nongovernmental Organizations. Social Forces 83 (2):587-620.

UCDP/PRIO. 2008. UCDP/PRIO armed conflict program. Available from http://www.prio.no/ CSCW/Datasets/Armed-Conflict/UCDP-PRIO/, accessed 28 September 2011.

UIA. 2008/2009. Yearbook of International Organizations Vol. 1-4. 45 ed. Union of International Associations.

Wallander, Celeste A. 2005. Ukraine's Election: The Role of One International NGO. CSIS, REP. Available from http://www.csis.org, accessed 1 March 2013.

WDI. 2010. World Development Indicators. World Bank. CD-Rom.

Weidmann, Nils B., and Kristian Skrede Gleditsch. 2010. Mapping and Measuring Country Shapes: The Cshapes Package. The R Journal 2 (1):18-24.

Weidmann, Nils, Doreen Kuse, and Kristian Skrede Gleditsch. 2010. The Geography of the International System: The CShapes Dataset. International Interactions 36 (1):86-106.

World Values Group Research. 1980-2008. Codebooks for World Values Survey. Ann Arbor, Mich.: Institute for Social Research. 